\title{
Remembering the Lost Palace: \\ Explaining and Engaging with the Absence of Constantinople's Great Palace
}

Isabel KIMMELFIELD

Once the heart of the Byzantine Empire, the grand stage on which the power and divinity of the emperor was presented and re-presented for over seven centuries, the Great Palace of Constantinople has today disappeared with barely a trace. In part, this is due to the waves of conquest and changing rule that left a greatly altered city in their wake: in I204, the palace was sacked by Latin Crusaders; after the Ottoman conquest of I453, what little remained of the building was gradually torn down, its pieces used elsewhere, its site built over. Later, urban development under Ottoman rule in the nineteenth century, and then under the Turkish Republic in the twentieth century further eroded and covered over the last remains of the palace.

Today, in a city filled with large and impressive monuments, the absence of the Great Palace is little felt by most visitors to modern Istanbul. Yet this absent monument nonetheless provides fertile ground on which to explore three key and interwoven - aspects of the construction of memories of monuments: the reasons for these monuments' survival or loss; the role of official efforts to unearth, reconstruct, and present these monuments; and the role of individuals to create their own 'memories' of monuments, about which they may know very little. This paper seeks to explore these themes as they are manifested in relation to the Great Palace. To this end, it will offer an exploration of the reasons for the palace's disappearance (in notable contrast to the neighbouring Hagia Sophia) followed by an overview of changing attitudes toward the preservation and presentation of cultural heritage (especially Byzantine) in Istanbul in the last hundred years. Within this context, the specific efforts made to excavate and present the Great Palace will be considered, as will the challenges these efforts faced. Finally, this paper will re- flect on the state in which these various efforts and attitudes have left the memory of the Great Palace, and the ways in which visitors today are able to encounter, conceptualise, and remember the remains of this lost monument.

\section{The Great Palace through the Ages}

For nearly nine hundred years, the Great Palace was the nerve centre of the Byzantine Empire. Begun under Constantine I, the palace grew over the centuries as various emperors added new sections and abandoned or pulled down old buildings. The space covered by this complex expanded to take up much of the land from the Hippodrome south-east almost to the Bosporos and from Hagia Sophia south-west to the Sea of Marmara. The complex included not only ceremonial halls and imperial and court residences, but also numerous chapels and shrines, walkways, gardens, and even a polo field. ${ }^{\mathrm{I}}$ Here the emperor, his family, and a vast number of courtiers, soldiers, and attendants could live and work, managing the empire and demonstrating and constructing imperial power through elaborate ceremonies. The palace complex abutted Hagia Sophia and there were three routes available to the emperor travelling from the Chalke Gate (the main entrance to the palace) to Hagia Sophia. He could cross the Augustaion and enter via the Horologion - the more public route; he could follow a colonnaded route from the Chalke to the Chapel of the Holy Well, located on the south-eastern corner of the Great Church, offering a more private approach; or, most private of all, he could use an enclosed walkway above the colonnade, by which route the emperor could pass unseen between the Chalke and the upper southeast level of Hagia Sophia. This opened directly onto the metatorion, the 
private imperial section of Hagia Sophia, almost an extension of the palace within the church. ${ }^{2}$ These routes were used at different times in different ceremonies according to requirement and preference.

The palace itself, with its churches and shrines, was an important religious centre in its own right, not least due to its collection of holy relics. By the late middle Byzantine period, this collection was famous even in distant lands, and pilgrims travelled from as far away as northern Russia to see these treasured objects, which included a large collection of Passion relics, housed in the Church of the Theotokos of the Pharos. ${ }^{3}$ Such relics, housed in the imperial residence rather than Hagia Sophia, underscored the power and particular divine position claimed by the Byzantine emperor. Emperors could display these objects to visiting foreign dignitaries and make use of them as means by which to swear important oaths. ${ }^{4}$

But somewhere around the end of the eleventh century, the Great Palace lost this central role. Under the Komnenian family, the main imperial residence moved to Blachernai Palace in the north-west of the city on the walls. While the churches of the palace continued to be used - and remained the sites of holy relics - the residential and ceremonial halls gradually faded from regular court usage, only appearing in sources for particularly grand ceremonial events. ${ }^{5}$ Excavations have revealed burials from the eleventh-thirteenth century cut through fourth-century mosaics, suggesting parts of the palace were used as a cemetery following its abandonment under the Komnenians. ${ }^{6}$ The palace did not suffer its true deathblow until I204, however. It was at this point, when the city was sacked by Latin Crusaders, that the sacred treasures of the Great Palace were carried off to Italy. When the city was retaken by the Byzantines in I26I, the Emperor Michael VIII Palaiologos stayed in the Great Palace for a short time following the re-conquest, but only temporarily while the Blachernai Palace was repaired following Latin occupation. ${ }^{7}$ Now denuded of most of its holy relics, the former Great Palace quietly decayed completely as the Byzantine capital entered its final centuries with its proces- sional routes reoriented between the Blachernai Palace and the still-standing Hagia Sophia. ${ }^{8}$ It was in this dilapidated and abandoned state when Mehmet II took the city in I453, at which point the new ruler of the city is said to have walked through the halls of the deserted and ruined palace and remarked upon its decline with a poetic quotation. ${ }^{9}$ Mehmet had a great interest in the empire that had previously ruled from Constantinople, and although it was important for him to assert his primacy over the city, he did not seek simply to erase the Byzantine past. Instead, he engaged in a complex discourse with the Byzantine monuments of the city - and in particular with the Christian buildings of the city. ${ }^{10}$ Hagia Sophia was not razed, but rather converted into a mosque, a deliberate and potent statement of conquest. But when it came time to build a new palace, Mehmet eschewed the site of the former Great Palace - an area now strewn with ruins. Instead he chose to construct Topkapi Palace on the ancient Acropolis of the Greek city of Byzantion, north of Hagia Sophia. In the building of this complex, he made use of spolia from the ruins of the Byzantine palace and hippodrome, and also gathered statuary and other objects from around the city. ${ }^{\mathrm{II}}$ The new palace also came to house an extensive collection of holy relics - echoing the role of the Byzantine palace centuries before, but not directly engaging with the now-lost monument. ${ }^{\mathrm{I} 2}$ The site of the Great Palace, meanwhile, was gradually covered by new houses, and, later, by the Sultan Ahmet Mosque. By the last decades of the Ottoman Empire, the Great Palace was long gone, built over many times over.

When the Republic was established in 1923 , Hagia Sophia was very deliberately converted from a mosque into a museum - a clear political statement of secularism on the part of Mustafa Kemal Atatürk. Hagia Sophia, with its religious use and meanings, remained - and remains today - a potent symbol in ongoing debates regarding the identity and image of modern Istanbul and Turkey. But the Great Palace, long ago stripped of its religious role, faded out of memory and hence, out of ongoing identity politics. Instead, it found itself buried beneath accruing layers of the Ottoman and then Republican city, 
small sections periodically coming to light. But even the identity of these ruins remains uncertain, as time and a lack of large-scale excavations have erased material markers of the layout of the Great Palace complex. ${ }^{\mathrm{I3}}$

\section{Early Approaches to Preserving and Presenting Byzantine Heritage in Istanbul}

Interest in the study and preservation of Turkey's Byzantine remains began in the late nineteenth and early twentieth centuries, during the last decades of the Ottoman Empire, roughly parallelling similar developments in Europe. ${ }^{14}$ In I869, the Magazine of Antiquities and the Magazine of Antique Weapons, housed in Hagia Irene, was renamed the Imperial Museum. At the same time, the new institution was moved, first to the Tiled Pavilion of Topkapi Palace, and later, in I89I, to a purpose-built neoclassical building. ${ }^{\text {Is }}$ The museum thus consciously and visually framed itself within museum traditions of Western Europe. The emphasis of the collections and their presentation, however, was not simply to 'copy' European traditions or conceptions of heritage and antiquities; the museum displayed classical works Western Europeans were familiar with as their own heritage - but these objects came from Turkish soil, thus suggesting the heritage of Western Europe was actually more native to the Ottoman Empire than to Western Europe. ${ }^{16}$ This emphasis on an all-encompassing view of heritage in Turkey was made even more explicit in 1906 and I9I2, when laws were passed for the preservation of monuments and antiquities 'from any period whatsoever'. In I9I5, the Council for the Preservation of Monuments was established to advise in the implementation of these laws. Ten years later, this council was re-ratified under the Republican government, and these laws remained in force until 1973 , indicating a degree of continuity in the development of attitudes toward cultural heritage and its management, despite the radical changes brought about by the 1923 revolution. ${ }^{17}$ Both the Ottoman and Republican governments sought to use Turkey's historical heritage to shape national identity, albeit to very different ends. The shifting agendas- political, ideological, commercial - that overlapped and at times came into conflict in the early twentieth century continue to influence decisions regarding heritage preservation in Istanbul to this day, with the fate of the remains of the Great Palace well reflecting the consequences of such vicissitudes.

In the early years of the Republic, Istanbul found itself in an uncertain role: although still the cultural heart of the nation, it had lost its status as the political capital. Its population plunged in the I930s as many inhabitants moved away, and parts of the city destroyed by fires remained un-developed, with neither the population pressures nor the funds to rebuild. ${ }^{18}$ There were, nonetheless, efforts to create a climate of cultural preservation. In the mid-I930s, the Ministry of Education issued a declaration to schools stating that all historic works, no matter the time period and historical label identifying them, were Turkish, 'and hence it is the duty of all Turks to preserve them'. ${ }^{\text {I9 }}$ This attitude was related to the 'Turkish History Thesis' in vogue at the time, which claimed that Turks originated in Central Asia, the origin of all human civilisations, and went on to influence all subsequent cultures and civilisations (including the GrecoRoman traditions embraced by Western Europe). ${ }^{20}$ Even preserved Byzantine monuments, notably Hagia Sophia, were included in this approach, and, indeed, were declared to have been made 'more Turkish' than Byzantine through Turkish repairs that had ensured their survival. ${ }^{21}$

Nonetheless, this 'inclusive' attitude toward these monuments had its limits, and this was somewhat to the detriment of the surviving palace remains. In 1938, the French urban planner Henri Prost submitted a proposal for an archaeological park in Istanbul. ${ }^{22}$ This area was defined by the Hippodrome, Hagia Sophia, and Great Palace region, while the Theodosian land walls were to encompass a protected zone. Prost envisioned not merely the preservation of standing monuments (specifically Hagia Sophia), but the reconstitution of the 'urban environment of the monument', as it had stood in the seventh century, including the Hippodrome and the Great Palace - a concept he had originally presented in a commissioned report from 


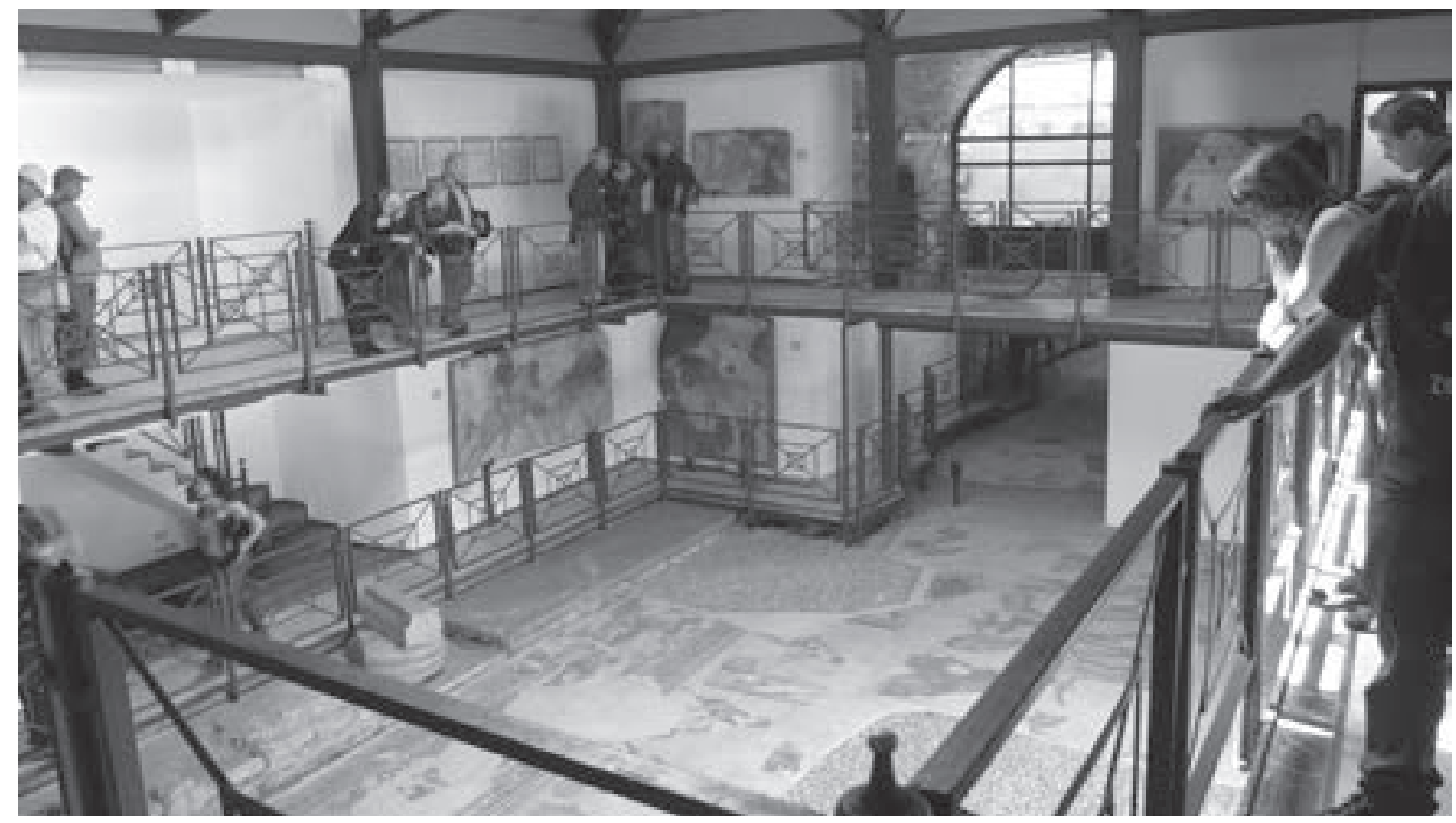

Fig. I. Istanbul, Great Palace Mosaic Museum. Photo by the author.

I9I I. ${ }^{23}$ In a paper presented to the Académie des Beaux-Arts in Paris in 1947, Prost explained his vision:

From this [Byzantine] period, only the large hippodrome and the Hagia Sophia are still intact. Yet, beneath the soil, on the ground level, there are most certainly very interesting remains. All new construction is prohibited in this area. Following the excavations, whether they would bear any fruit or not, at least a space will be opened between the Hagia Sophia and Sultan Ahmed, where the Byzantine remains can be displayed within a park surrounded by greenery, a park duly named as the Archaeological Park. ${ }^{24}$

This proposal was criticised by some in Turkey, who objected to the use of Byzantine remains to define the perimeters of this park, which was seen as 'erasing', or at least de-emphasising, the Ottoman history of the area. ${ }^{25}$ Thus, although in the protected region surrounding Sultanahmet Square several important monuments and buildings, including Byzantine ones, are preserved, Istanbul lacks a true archaeological park. Only buildings still standing above ground were preserved, while the
Great Palace region was rapidly built over in the I950s, which saw extensive urban development programmes as the population increased I $30 \%{ }^{26}$

\section{Excavations: Challenges and Compromises}

Before this development took place, a number of efforts were made to survey and even conduct limited excavations of the Great Palace site. The first effort at a comprehensive survey of the region was undertaken by Ernest Mamboury and Theodor Wiegand in I9I8 following two fires that razed the modern buildings in the area in I9I2 and 1913. ${ }^{27}$ They set about mapping and investigating all Byzantine ruins that could be observed without excavation and, in 1934, published their findings in a guidebook titled Die Kaiserpaläste von Konstantinopel zwischen dem Hippodrom und dem Marmara-meer. This was illustrated with photographs and plans and was intended not only as an archaeological report, but also as a handbook for the informed visitor seeking to explore the remains of Byzantine Istanbul. ${ }^{28}$

Another fire in 1933 enabled the first true excavation of the Great Palace site. This was con- 


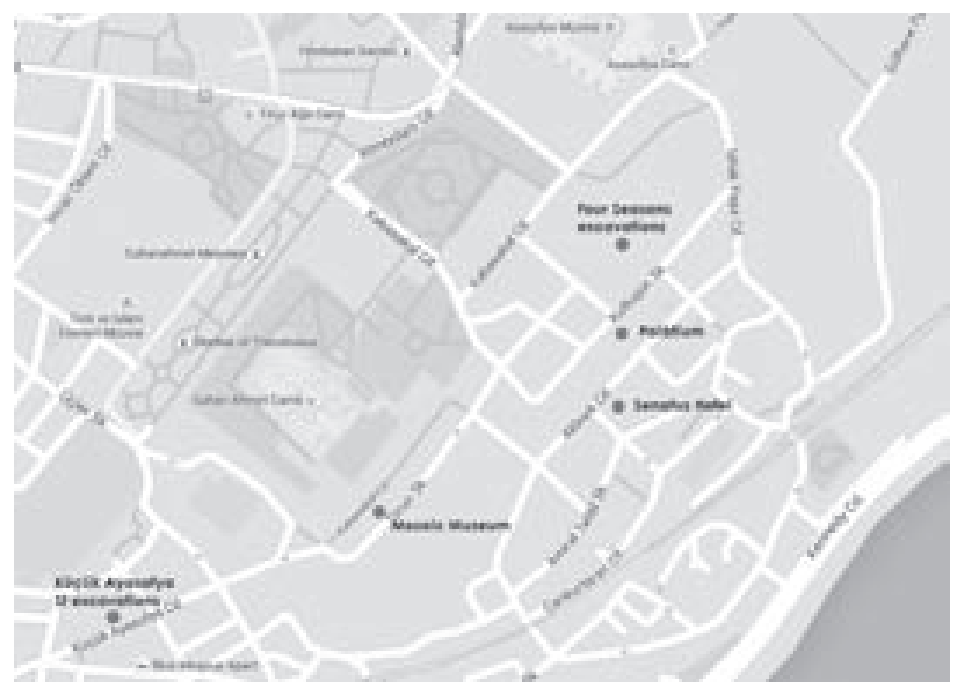

Fig. 2. Map of Istanbul showing the locations of the Mosaic Museum, the Four Seasons excavations, the Senatus Hotel and the Palatium Café. Map: Google, edited by the author.

ducted between 1935 and 1938, funded by the Walker Trust (University of St Andrews), with reports of the excavations published in 1947 and I958. These excavations concentrated on an area just to the east of the Blue Mosque. Despite the fire, the region was still relatively built-up, limiting the excavation to small areas, occasionally connected by tunnelling under Turkish walls. ${ }^{29}$ The most famous discoveries yielded by this excavation were the mosaic floors of a peristyle belonging to the Great Palace. These mosaics, dating to the sixth century, had been protected by accumulated debris and Byzantine-era marble slabs..$^{\circ}$ Following the excavation, a temporary shelter was erected over the mosaics by the Directorate General of Monuments and Museums and they were maintained in situ for visitors. However, the roof was inadequate and the initial efforts to preserve the mosaics using cement mortar and fillers caused damage, so that by I979, the site had to be closed down for repairs. In search of funds, the Directorate sought foreign investment, resulting in the AustrianTurkish research project for the Palace Mosaic of Constantinople. ${ }^{3 \mathrm{I}}$ This enabled the mosaics to be properly conserved and re-laid and permanent structure erected. In I987, the site reopened as the Great Palace Mosaic Museum. Today, this is the only official site or museum devoted to the remains of the Great Palace (Fig. I).
Following the Walker Trust excavations, the region was heavily developed in the I950s and I96os, further limiting the scale on which excavations in the region can be carried out. Today, archaeologists must take advantage of demolition work, excavating before new buildings are erected. In I994, permission was granted by the Istanbul Cultural and Natural Heritage Protection Committee for excavations to take place on Küçük Ayasofya Street (Fig. 2). This was the site of the southern end of the palace complex, which was expanded in the seventh through tenth centuries as the older, northern sections fell out of use. Excavation work continued in intervals until I996, and discoveries included a fifth-, sixth-century mosaic, and remnants of a water-related structure. ${ }^{32}$ Eleven third- to second-century BC graves were also found, part of a necropolis, indicating the limits of the Hellenistic city of Byzantion. The 1994 local elections brought a new municipal administration, though, which ultimately ended work on the site. ${ }^{33}$ In 1997, permission was granted to the Eresin Crown Hotel, which was constructed on the site, to preserve the mosaic in situ and use stone artefacts found in the dig as decoration in the new building (Fig. 3). ${ }^{34}$

The difficulties surrounding these sites were even more clearly demonstrated in the excavations carried out on the site of the Sultanahmet 


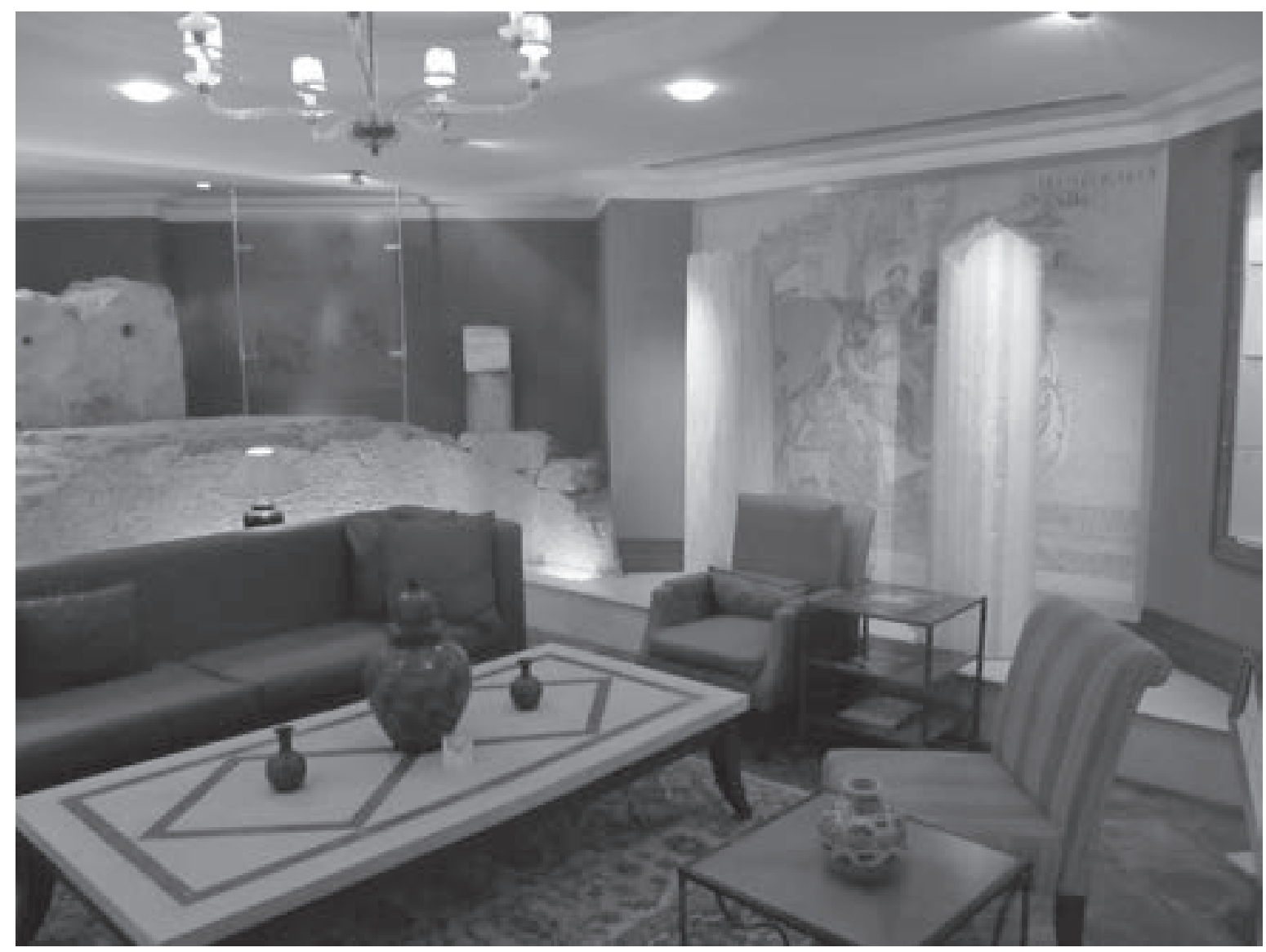

Fig. 3. Great Palace remains on display, Istanbul: Eresin Crown Hotel. Photo by the author.

Four Seasons Hotel between 1997 and 2008. This site, southeast of Hagia Sophia, where the Chalke Gate, Magnaura, and Senate House would have been located in the Great Palace (Fig. 2), was known to contain Byzantine remains from I9II, when Mamboury and Wiegand observed the construction of an Ottoman prison (later converted into the hotel). ${ }^{35}$ In 1997, restoration work on the hotel revealed extensive Byzantine substructures. What happened next is difficult to ascertain. The hotel paid the Istanbul $\mathrm{Mu}$ seum of Archaeology to conduct excavations, but they also wished to build on the site and applied for permits to do so. These were granted by the Preservations Commission, the body responsible for granting building permits in areas of archaeological interest. The then-director of the Istanbul Archaeological Museums, Alpay Pasinli, was also a member of the Commission, and was subsequently accused of putting pres- sure on the Commission to grant these permits due to his political, business, and union connections. The Turkish press further alleged that Pasinli had been involved in artefact smuggling, after which Pasinli stopped speaking to journalists. In 2008, a court ruling declared that the excavation had been carried out illegally and the site was shut down. ${ }^{36} \mathrm{~A}$ deal had been made between the city and the Sultanahmet Construction Company, allowing them to expand the hotel, provided they sponsored the excavations and developed the site into an archaeological park. But it was alleged that the expansion work would damage the site, and that the park would be enclosed in the hotel, not open to the public. Despite insistence from parties on both sides of the conflict that the site would be opened to the public once the matter was settled, it remains fenced off and no further excavation work has been carried out. 
This situation reveals the challenges preventing thorough investigation and presentation of the remains of the Great Palace in a region where urban development has created a complex, conflicting web of interests, including political agendas, local and national government bureaucracies, private businesses, and those responsible for preserving cultural heritage. In the case of the Four Seasons excavations, this has caused a fascinating and important site to go unexplored. Some preliminary work was conducted in the area and the report on the excavation indicates the exciting nature of the discoveries the site could yield. These include the possible remains of the foundations of the Chalke Gate, once the main entrance to the Great Palace. ${ }^{37}$ Another set of Byzantine substructures might correspond to a building called the 'Arslanhane' (House of Lions) by the Ottomans, used to house the sultan's lions, but in Byzantine times a church, possibly one erected by John I Tzimiskes. ${ }^{38}$ The report stressed, however, that such attributions could only be tentative until a larger team, including more specialists on the period, could be assembled to investigate the site.

\section{Presenting the Palace: A Personal Experience}

Given such difficulties in conducting largescale excavations in the region, it is perhaps not surprising that the most extensive sections of the Great Palace accessible to visitors today are those that have been excavated by private businesses, underneath their properties. This has often been done at the business-owner's expense, possibly in part to avoid the multitude of bureaucratic issues that can arise from official excavations. These private efforts are notable in light of the relative lack of emphasis placed by official tourist sites in the area on the remains of the Great Palace. The only official site dedicated to these remains, the Mosaic Museum, is presented as an adjunct to the Hagia Sophia museum, with minimal information available on the official website, www.ayasofyamuzesi. gov.tr. Thus, given limited public awareness of the original location of the Great Palace or its history, it is interesting to note the number of businesses in the region that have chosen to use its legacy to add an element of historical interest to their services. This runs from simple allusions through hotel and shop names, to large-scale excavations (Fig. 2). The Senatus Hotel on the Akbiyık Caddesi, for instance, has no excavations, but until recently it included information on its website informing visitors about the history of the Great Palace, and explaining that the hotel's name stems from its location, near the original site of the Palace Senate House. ${ }^{39}$

One street away from the Senatus, down the street from the Four Seasons, sits the Palatium Café, where visitors can wander through a series of Byzantine vaulted chambers. ${ }^{40}$ This cafe, whose name today clearly refers to the palace, was formerly the Asia Minor Carpet shop, owned by the Başdoğan family. In 1999, the first Byzantine ruins were discovered beneath the shop, and since then the family has paid to have the chambers excavated. In 2007, these excavations were featured on the History Channel show Cities of the Underworld. Today, the Palatium continues to open these rooms to the public, free of charge, though the excavations are little advertised. Travel blogs and tourist sites suggest that not all who visit these rooms are even aware that these are the remains of the Byzantine Great Palace (despite a few information signs). ${ }^{41}$ But whatever people's knowledge of the history of the palace, their accounts clearly indicate that exploring these remains is exciting, and, in some ways, the lack of wider advertising or an official presentation makes each person's encounter more personal and the memory therefore more special. ${ }^{42}$

Although there are no government-sponsored comprehensive guides to these diverse encounters with remains of the Great Palace, they are listed in various tourist handbooks, and at least one academic project has sought to transfer its discoveries into a useable guidebook for nonacademic visitors. The Byzantium I200 project produces digital reconstructions of medieval Constantinople, and in 2007 they published a book titled Walking Thru Byzantium: The Great Palace Region. ${ }^{43}$ This handbook is intended to allow visitors to reconstruct their own 'memory' of the Great Palace, offering a walking tour through the region highlighting sites and re- 
mains, both official and unofficial. To complement these encounters, the handbook is extensively illustrated with the digital reconstructions of the palace buildings, offering visitors an impression of the original context of the remains they can see today. These reconstructions are based on primary sources from the Byzantine period as well as on modern excavations and surveys, making it in essence an updated version of the book produced by Mamboury and Wiegand in I934.

Besides these sites, some artefacts from excavations are also on display today in the Istanbul Archaeological Museums. The grandest of these objects are two stone lions, which today flank a museum staircase (Fig. 4). These originally stood in the Boukoleon Palace on the Sea of Marmara, which was incorporated into the Great Palace in the tenth century. They likely once overlooked a set of marble steps leading to the mooring for imperial ships, and continued to stand among the ruins of the palace until I87I, when these ruins were demolished and the lions were removed to the museum. ${ }^{44}$ Along with the Great Palace mosaics, these lions are the only surviving indicators of the splendour with which the palace was once decorated and the awesome impact it must once have had. The other objects on display in the museum are smaller items, like pottery, or small architectural elements. In 20II, an exhibition was staged, titled Byzantine Palaces in Constantinople. Remains were displayed from a number of palaces, imperial and non-imperial, throughout the city, and by far the greatest number of objects came from the Great Palace. These were limited in size and variety, but indicate the wealth of remains that lie beneath the ground, still undiscovered. ${ }^{45}$

\section{Conclusion}

Long ago stripped of its sacred and ceremonial role and, as a result, allowed to fade from sight and public discourse, the Great Palace of Constantinople will never rival Hagia Sophia as the great Byzantine monument of Istanbul. But it is not as lost as it might at first appear to be, although presenting it as a cohesive monument will never be possible. The very premise of

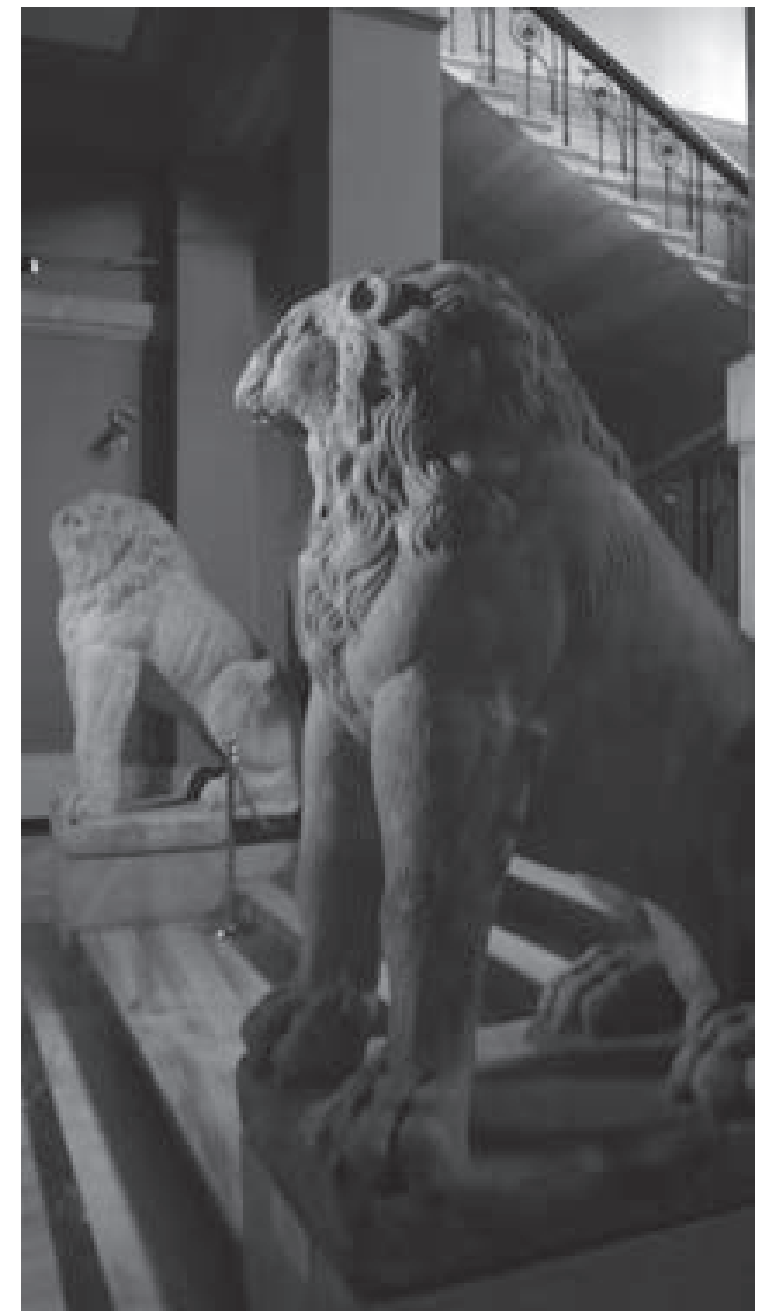

Fig. 4. Stone lions from the Boukoleon Palace, Istanbul: Istanbul Archaeological Museums. Photo by the author.

Walking Thru Byzantium indicates the difficulty of this enterprise: with these various remains spread out in both space and ownership, the onus is on visitors to make the effort to connect the dots and construct for themselves a memory of the lost palace. Yet at the same time, this fact itself has some appeal: for those exploring the underground corridors of the palace that lie beneath ordinary restaurants, cafés, and shops, there is a feeling of 'discovering' the palace for themselves. These encounters are surprisingly personal for a monument that once symbolised the exclusivity and separateness of the Byzantine imperial court, but that in part may account for some of their allure. Extensive excavations of 


\section{Remembering the Lost Palace}

the Great Palace region will never be possible, and so the experience of the palace will remain fragmentary and individual, but there will always be visitors who, in the heart of the tourist centre of Istanbul, will enjoy the feeling of a private encounter with the past, no matter how

\section{Notes}

I J. Michael Featherstone, 'Luxury in the Palace: The Buildings of Theophilus', Istanbul Araştırmaları Yilliğı, 3 (2OI3), 33-40.

2 Gilbert Dagron, Emperor and Priest: The Imperial Office in Byzantium (Cambridge: Cambridge University Press, 2003), p. 96; Cyril Mango, The Brazen House: A Study of the Vestibule of the Imperial Palace of Constantinople (Copenhagen: I kommission hos Munksgaard, I959), pp. 73-92.

3 Robert Ousterhout, 'Constantinople and the Construction of a Medieval Urban Identity', in The Byzantine World, ed. by Paul Stephenson (London: Routledge, 20I0), p. 336; George Majeska, 'Russian Pilgrims in Constantinople', Dumbarton Oaks Papers, 56 (2002), 93-108. Nikolaos Mesarites, who served as custodian of these treasures at the end of the twelfth century, also described in detail the Passion relics at the Pharos-Church in his 1207 account of the I2OI revolt of John Komnenos, indicating the ongoing activity that took place in the Great Palace up to the Latin occupation. But for all pilgrims, before and after the Latin occupation, Hagia Sophia remained the primary site to visit.

4 Holger A. Klein, 'Sacred relics and imperial ceremonies at the Great Palace of Constantinople', in Visualisierungen von Herrschaft, ed. by F. Bauer $(=B Y Z A S$, 5 (2006)), pp. 75-99.

$5 \quad$ Wolfgang Müller-Wiener, Bildlexikon zur Topographie Istanbuls: Byzantion - Konstantinupolis - Istanbul bis zum Beginn des 17. Jahrhunderts (Tübingen: Wasmuth, I977), p. 235. Even before this shift, older sections of the palace had already fallen out of use (apart from some special occasions) and were in varying states of disrepair from the late ninth century if not earlier. J. Michael Featherstone, 'The Great Palace as Reflected in the "De Ceremoniis", in Visualisierungen von Herrschaft, ed. by F. Bauer (= BYZAS, 5 (2006)), pp. 47-6I (pp. 47-49).

6 Exh. cat. Istanbul: Archaeological Museums, Byzantine Palaces in Constantinople | Istanbul'daki Bizans saraylari, ed. by Asuman Denker (Istanbul: Bosphorus Books, 20II), p. 25.

7 Alice-Mary Talbot, 'The Restoration of Constantinople under Michael VIII', Dumbarton Oaks Papers, 47 (I993), 243-6I (p. 250).

8 The Pharos and the Nea churches of the Old Palace still stood and appear in pilgrim texts, but they much or how little they know or understand of its rich history. The palace thus presents itself in glimpses, with reconstructions of it in its entirety remaining only speculative, leaving it up to each individual to construct his or her own memory of the Great Palace of Constantinople.

lay in increasingly dilapidated surroundings and the substructures of the Old Palace were used as a prison. Müller-Wiener, p. 236.

9 Gülru Necipoğlu, Architecture, Ceremonial, and Power: The Topkapi Palace in the Fifteenth and Sixteenth Centuries (Cambridge: The MIT Press, I99I), p. 3.

Io Çiğdem Kafescioğlu, Constantinopolis/Istanbul: Cultural Encounter, Imperial Vision, and the Construction of the Ottoman Capital (University Park: Pennsylvania State University Press, 2009), p. I8.

I I Kafescioğlu, pp. 59-60. Kafescioğlu argues that the location of the palace on the old Greek acropolis linked the new Ottoman rule with Byzantium's even more ancient predecessors by harking back to the city's earliest foundations. Topkapi was actually the second palace built under Mehmet; the first, the Old Palace, was built on the site today occupied by Istanbul University.

I2 Julian Raby, 'A Sultan of Paradox: Mehmed the Conqueror as Patron of the Arts', Oxford Art Journal, 5, I (1982), 3-8 (p. 6).

I3 Scholars have attempted to reconstruct hypothetical layouts on the basis of accounts of ceremonial processions - in particular as found in the tenth-century Book of Ceremonies. See in particular the works of Featherstone, Mango, Jonathan Bardill, and Jan Kostenec on this, as well as the pioneering work of Jean Ebersolt, Le Grand Palais de Constantinople et le Livre des Céremonies (Paris: Leroux, I9IO).

I4 Engin Akyürek, 'Byzantine Art History in Modern Turkey', in Perceptions of the Past in the Turkish Republic: Classical and Byzantine Periods, ed. by Scott Redford and Nina Ergin (Leuven: Peeters, 20Io), pp. 207-24 (p. 206).

I5 Wendy Shaw, 'Museums and Narratives of Display from the Late Ottoman Empire to the Turkish Republic', Muqarnas, 24 (2007), 253-79 (pp. 256-58).

I6 Shaw, p. 259.

I7 Nur Altinyildiz, 'The Architectural Heritage of Istanbul and the Ideology of Preservation', Muqarnas, 24 (2007), 28I-305 (pp. 286-87).

I8 Shaw, p. 269; Altinyildiz, p. 288.

I9 Altinyildiz, p. 29I; Murat Ergin, 'Archeology and the Perception of Greek, Roman, and Byzantine Eras in Early Republican Turkey', in Perceptions of the Past in the Turkish Republic: Classical and Byzantine Periods, ed. 
by Scott Redford and Nina Ergin. (Leuven: Peeters, 2010), pp. 13-33 (p. 27).

20 Scott Redford and Nina Ergin, 'Introduction', in Perceptions of the Past in the Turkish Republic: Classical and Byzantine Periods, ed. by Scott Redford and Nina Ergin (Leuven: Peeters, 20Io), pp. I-33 (p. 4).

2 I Altinyildiz, p. 292.

22 Ibid., p. 292.

23 Pierre Pinon, 'Henri Prost, Albert Gabriel, Istanbul Archaeological Park and the Hippodrome', in Hippodrome/Atmeydani: A Stage for Istanbul's History, ed. by Brigitte Pitarakis (Istanbul: Pera Museum, 20Io), pp. 252-67 (p. I53).

24 Pinon, p. I53.

25 Ibid., pp. 292, 295. In an era notable for distancing itself from the immediate Ottoman past, this is an interesting objection, and indicates the way in which Istanbul in the period I923-c. I950 may be seen as having been used to demonstrate the decay of the empire by preserving its monuments just enough that (Turkish) visitors could witness the disrepair into which that empire had fallen.

26 Altinyildiz, p. 295; Akyürek, p. 209.

27 Jonathan Bardill, 'Archaeologists and Excavations of the Hippodrome', in Hippodrome/Atmeydam: A Stage for Istanbul's History, ed. by Brigitte Pitarakis, (Istanbul: Pera Museum, 2010), pp. 83-90 (pp. 87-88).

28 Günter Martiny, 'The Buildings', in The Great Palace of the Byzantine Emperors: Being a First Report on the Excavations Carried out on Behalf of the Walker Trust (The University of St Andrews) 1935-1938, ed. by David Talbot Rice (Oxford University Press, I947), p. I.

29 Martiny, p. 2.

30 Henry Maguire, 'The Medieval Floors of the Great Palace', in Byzantine Constantinople: Monuments, Topography and Everyday Life, ed. by Nevra Necipoğlu (Leiden: Brill, 200I), pp. I53-74 (pp. I54-57, I74). Maguire suggests that the mosaics were covered due to changing tastes which preferred plainer (though still expensive) floors and brilliantly decorated ceilings.

3I From display in the Mosaic Museum, Istanbul.

32 M. Gökçay Metin and Rahmi Asal, 'Excavations in Küçük Ayasofya Street, Eminönü, Istanbul', Anatolia Antiqua, I6 (2008), 207-30 (p. 207).

33 Mehmet Tunay, 'Byzantine Archaeological Findings in Istanbul During the Last Decade', in Byzantine Constantinople: Monuments, Topography and Everyday Life, ed. by Nevra Necipoğlu, (Leiden: Brill, 20oI), pp. 217-3I (p. 223).

34 Gökay and Asal, p. 2 I6.

35 John Gorvett, 'A Byzantine Plot?' Archaeology, 5I, 6 (November-December 1998) <http://archive.archae-
ology.org/98II/newsbriefs/byzantine.html> [accessed 30 November 2015].

36 Arif Bayraktar, 'Excavation halted in Eminönü', Today's Zaman, I2 November 2008 <http://www.todayszaman.com/news-I58429-excavation-halted-ineminonu.html> [accessed 30 November 2015]. This suit was brought by the Istanbul provincial chairman of the Republican People's Party against the Istanbul Metropolitan Municipality and the Ministry of Culture and Tourism, suggesting the way in which politics and cultural heritage are still intertwined today.

37 Çigdem Girgin, 'La Porte Monumentale trouvee dans les fouilles pres de l'ancienne prison de Sultanahmet', Anatolia Antiqua, I6 (2008), 259-90 (p. 273).

38 Girgin, p. 265.

39 Senatus Hotel <http://www.senatushotel.com/> [accessed I December 20I5]. Following an update of the website, this PDF was removed, but the name remains.

40 The Albura Kathisma Restaurant, near the Senatus Hotel, has also excavated Byzantine substructures beneath the modern building and opened them to visitors free of charge.

4I Reviews on the Tripadvisor page of the café include numerous references to the excavations, although not all visitors correctly identify these remains as belonging to the Byzantine Great Palace: 'Palatium Café \& Restaurant', <http://www.tripadvisor.co.uk/Restaurant_Review-g293974-dI940629-Reviews-Palatium_Cafe_Restaurant-Istanbul.html $>$ [accessed 30 November 20I5].

42 Examples of the personal blogs recounting visits to these excavations: 'Istanbul: Sultanahmet's Secret underworld - Palatium', Turkey's For Life, i8 December 20IO. <http://www.turkeysforlife.com/2OII/I2/ istanbul-sultanahmets-secret-underworld.html $>$ [accessed 30 November 20I5]; Courtney Mroch, 'The Lost World Beneath the Palatium Café', Haunt Jaunts, 5 April 2012 <http://www.hauntjaunts.net/thelost-world-beneath-the-palatium-cafe-and-restaurant/> [accessed 30 November 20I5]; Trici Venola, 'Just Under Your Feet: Drawing the Corridors of Lord', Drawing on Istanbul <http://tricivenola.wordpress.com/> [accessed 30 November 20I5]. Venola, a graphic artist, has drawn the interior extensively, and produced a detailed schematic of the excavations to 2005 . She is interested in the history of the palace, and includes information and illustrations on her website indicating the possible original layout.

43 Jan Kostenec, Walking Thru Byzantium: Great Palace Region (Istanbul: Grafbas, 2007).

44 Jonathan Harris, Constantinople: Capital of Byzantium (New York: Bloomsbury, 2007), p. 202.

45 Exh. cat. Istanbul, Byzantine Palaces in Constantinople. 